\title{
The Original Living Tree
}

\section{Asher Honickman*}

One of the main arguments in Canada in favour of the "living tree" doctrine is that it has deep roots in our constitutional tradition. As the Supreme Court of Canada said in Reference Re Same-Sex Marriage, the living tree is "one of the most fundamental principles of Canadian constitutional interpretation." The argument goes something like this: beginning with the famous "Persons case" of 1929 (Edwards v. Canada (Attorney General)), ${ }^{2}$ the Judicial Committee of the Privy Council recognized the Constitution to be a living tree, capable of evolving to meet new social and economic realities, and this method of constitutional interpretation has remained fundamental to Canada's constitutional order ever since. $^{3}$

In recent years, several commentators, most notably Justice Bradley Miller (then a Professor at the University of Western Ontario), have refuted this version of Canadian history. ${ }^{4}$ They have demonstrated that the Privy Council's decision in Edwards was a standard exercise of statutory interpretation and textual analysis. The reference to the living tree remains somewhat ambiguous, but Lord Sankey, the decision's author, appears to have said that Canada's constitutional order - most notably, its unwritten constitutional principles and the common law - was independent of Britain. ${ }^{5}$ Whatever else may be said about the decision, the Privy Council was clearly not endorsing the principle that the meaning of the Constitution should change to reflect the values of modern society.

The Privy Council followed the "living tree" passage with an admonition that the Constitu- tion should not be interpreted in a "narrow and technical" manner, but should rather be given a "large and liberal interpretation." The Privy Council acknowledged the well-established rule that the then British North America Act, $1867^{7}$ (now the Constitution Act, 1867) ${ }^{8}$ should be interpreted "by the same methods of construction" as other statutes. This would have necessarily included the original or fixed meaning as canon, which holds that "the words of a statute must be construed as they would have been the day after the statute passed." 10 The Privy Council, however, distinguished between penal and taxing statutes - that ought to be interpreted strictly - and other statutes passed to ensure the peace, order, and good government of a British colony. ${ }^{11}$

Two years after Edwards was decided, the Supreme Court married the "living tree" passage to the "large, liberal" interpretation afforded to constitutional statutes. ${ }^{12}$ It is not clear that Lord Sankey intended to connect the two concepts; but in any event, the Court's interpretation of the "living tree" was a far cry from the modern "living tree" doctrine, which only began to emerge in Canada in the 1970s and came into full fruition during the early Charter era. What is more, granting the BNA $A c t^{13}$ a large and liberal construction was hardly a new or radical proposition in 1929. The Privy Council in Edwards relied on W.H.P. Clement's The Law of the Canadian Constitution, ${ }^{14}$ third edition, which had been published in 1916, in support of this proposition. ${ }^{15}$ And, indeed, the early constitutional scholar, A.H.F. Lefroy, had written as early as 1897 that one of the leading propositions of the BNA Act 
was that it "cannot be construed in a rigidly technical manner." ${ }^{16}$

It is perhaps because Edwards was seen as affirming an already-established and relatively uncontroversial proposition of constitutional interpretation that the decision fell into obscurity so soon after it was decided. It was cited in a handful of decisions in the early 1930s, but rarely again after that until it re-emerged in the late 1970s. The Supreme Court did not utter the phrase "living tree" between 1931 and 1979, and the phrase did not appear in any Canadian decision between 1936 and $1972 .{ }^{17}$

$$
* * *
$$

Legal scholars continued to discuss Edwards during this long interval, but never for the proposition that it supported a progressive interpretation of the Constitution. ${ }^{18}$ As with the courts, they tended to view Edwards, at most, as breathing new life into an existing principle - that the $B N A$ Act should not be interpreted too rigidly - as opposed to establishing a new principle of progressive interpretation. Two examples are particularly instructive: the 1939 O'Connor Report, ${ }^{19}$ and G.P. Browne's 1967 text The Judicial Committee and the British North America Act, ${ }^{20}$ which was written largely in response to the O'Connor Report. I single out these two because both dealt expressly with the correct interpretation of the BNA Act, and both discussed the impact of the decision in Edwards on the proper method of constitutional interpretation. As I argue below, both authors, despite writing nearly three decades apart and despite disagreeing to some extent on the nature of the division of powers, understood that the BNA Act was to be construed in accordance with traditional principles of statutory interpretation.

\section{The O'Connor Report}

William F. O'Connor wrote his report following three decisions from the Privy Council that had invalidated a number of federal New Deal laws. ${ }^{21}$ O'Connor assailed the Privy Council as an "imperial judicial tribunal" 22 and argued that its decisions had created a decentralized federa- tion in which neither order of government could properly address the Great Depression. ${ }^{23}$ Notably, however, O'Connor did not argue that the interpretation of the Constitution should evolve to accommodate modern realities - that the courts, in other words, should confer more powers upon Parliament so that it may respond more effectively to the Great Depression. Rather, the Privy Council had betrayed the original meaning of the text, which he considered to be centralist in character.

Interestingly, O'Connor cited Lord Sankey's less known "Sixty Colours" analogy from the Aeronautics Reference ${ }^{24}$ in support of his argument that courts must conduct a bare textual analysis. ${ }^{25}$ In that decision, Lord Sankey warned against judicial interpretations moving slowly but surely away from the original meaning of the text and emphasized that jurists ought to "get back to the words of the Act itself and to remember the object with which it was passed." ${ }^{26}$ If that were not clear enough, he added that " $\mathrm{t}]$ he process of interpretation as the years go on ought not to be allowed to dim or to whittle down the provisions of the original contract upon which the federation was founded." ${ }^{27}$

With respect to how the text should be interpreted, O'Connor acknowledged at the outset that the BNA Act was a statute and that "nearly all rules relative to the interpretation of statutes in general apply to it." ${ }^{28}$ What distinguished the BNA Act from other statutes was that it served as a constitutional charter and enabled the making of other statutes. Since it did not contain an amendment provision, "it must have been intended to have more flexibility than an ordinary statute."29 At this point, O'Connor cited the "living tree" metaphor from Edwards $s^{30}$ in conjunction with dicta from the Privy Council's decision in British Coal Corporation and others v. The King ${ }^{31}$ that the $B N A$ Act should be liberally construed. ${ }^{32}$

O'Connor went on to discuss some Australian and English cases and then returned to the Canadian context, citing Bank of Toronto $v L_{\text {Lambe }}{ }^{33}$ for the proposition that the courts "must treat the provisions of the Act... by the same methods of construction and exposition which they apply to other statutes"; he then cited 
Edwards again for the proposition that constitutional statutes should be granted a large and liberal interpretation. ${ }^{34} \mathrm{He}$ concluded by discussing basic principles of interpretation applicable to all written instruments, namely that the words should be read in their grammatical and ordinary sense and that the "nature, history and ends" of a statute should not even be considered unless necessary to resolve ambiguity, clarify obscurity, or overcome absurdity. ${ }^{35}$

Thus, for O'Connor, text was paramount, and in discerning its meaning, the courts should rely primarily on the ordinary meaning of the words. The BNA Act should be construed with some greater elasticity, but it remained, at its core, a statutory enactment subject to the ordinary rules of interpretation. O'Connor devoted the balance of his report to attacking Privy Council decisions on textual grounds, honing in on the opening paragraph of section 91 . Not only did his analysis steer clear of progressive interpretation, it paid little more than lip service to the more modest "large and liberal" version of the "living tree." If anything, his analysis was overly technical and legalistic, admonishing the Privy Council for appealing to the larger purposes underlying the BNA Act. ${ }^{36}$

\section{The Judicial Committee and the British North America Act}

Gerald P. Browne was a Canadian historian, perhaps best known as the editor of Documents on the Confederation of British North America, ${ }^{37}$ which remains one of the definitive primary source texts in Canadian constitutional history. In 1967, when he authored The Judicial Committee, ${ }^{38}$ the notion of a "living constitution" had already been accepted by many jurists in the United States, and new instrumentalist legal philosophies, which de-emphasized the text in favour of "cultural, social and economic realities," 39 were already dominant in Canadian academia. ${ }^{40}$ And yet, Browne's text is steeped in the old formalism and what historian Richard Risk called "rule of law thought." ${ }^{41}$ It is possible that, as an historian, Browne had not yet been thoroughly exposed to new jurisprudential philosophies, though his writing suggests at least a passing familiarity. ${ }^{42}$ It may be that he simply did not give these new ideas much credence. In any event, his classically textual analysis offers persuasive evidence that the new jurisprudential theories in general and the progressive "living tree" doctrine in particular had not yet become orthodoxy in the wider legal and intellectual communities as they would over the next few decades.

Thus, Browne took on O'Connor on his turf. Rather than appealing to changing social circumstances that could justify a less centralist federation (such as the Quiet Revolution then underway in Quebec), Browne fought O'Connor's textual arguments for centralism with textual arguments of his own, which, in his view, supported the coordinate sovereignty model endorsed by the Privy Council.

Browne began his analysis, much in the same way as O'Connor had done, by discussing the underlying principles of constitutional interpretation. Like O'Connor, he cited the Privy Council's decision in Bank of Toronto $v$ Lambe $^{43}$ for the basic proposition that the BNA Act was a statute and should be interpreted as such. He also quoted the entirety of the "living tree" and "large and liberal" paragraphs from Edwards. But whereas O'Connor saw the two decisions working in tandem with Edwards merely qualifying Lambe, Browne saw them as being in conflict and representing two distinct lines of authority emerging from the Privy Council. He referred to the former as the "literal approach" and the latter as the "constituent statute argument." ${ }^{4}$

The constituent statute argument was essentially that the BNA Act, being a constitutional statute, should be interpreted more liberally than an ordinary statute. As noted above, this proposition goes all the way back to early Privy Council decisions and to Lefroy's leading constitutional propositions. But Browne argued that the constituent statute approach was, in fact, a departure from the way in which the Privy Council had typically interpreted the Act and was, at best, an undertow against the strong literalist current.

In support of the literalist approach, Browne cited the Lambe decision, along with the Labour 
Conventions Reference ${ }^{45}$ decision of 1937, in which Lord Atkin had referred to the jurisdictional spheres as "watertight compartments." But he also cited Lord Sankey's statement in Edwards that "the question is not what may be supposed to have been intended, but what has been said," 46 which is far less quoted than the "living tree" passage but far more indicative of the approach undertaken by the Privy Council in that case. Browne thus relied on Edwards both in support of the constituent statute argument and the more dominant literalist approach.

Browne went on to discuss the development of the constituent statute approach, which he acknowledged preceded Edwards while maintaining that it was "explicitly approved and possibly adopted" in that decision. ${ }^{47}$ The Privy Council approved of this approach in a couple of subsequent decisions, notably British Coal in which the Privy Council upheld the authority of Parliament to prohibit criminal appeals to the King in Council, and Attorney-General of Ontario v. Attorney-General of Canada and others, ${ }^{48}$ the seminal decision that confirmed Parliament could abolish all appeals to the Privy Council. In both cases, the Privy Council had endorsed the view that the BNA Act, being an "organic statute," should be interpreted flexibly to allow for the "widest possible amplitude" of federal power. ${ }^{49}$ Both decisions endorsed a "large and liberal" reading of the BNA Act, but both were also anchored fundamentally to the recent enactment of the Statute of Westminster, 1931, ${ }^{50}$ which had, in some respects, expanded the power of Parliament. Thus, while the Privy Council was prepared to consider a changing constitutional landscape, there is no indication that it was ever prepared to consider changing social norms.

Moreover, according to Browne, these decisions were in the minority: "In by far the majority of cases it was the approach adopted in Bank of Toronto $v$. Lambe, rather than the one reflected in Edwards v. Attorney-General for Canada, that prevailed." ${ }^{51}$ Browne quoted from a 1937 Harvard Law Review article written by progressive constitutionalist Ivor Jennings which had concluded that the Privy Council "has never seriously wavered from the principle that it was their function to interpret the intention of Parliament' as laid down in the Act and not to fit the Constitution to the changing conditions of social life". ${ }^{2}$ Browne concluded that the Privy Council had essentially rejected the constituent statute argument. ${ }^{53}$

Browne's analysis offers an insight into how Edwards was viewed nearly four decades after it had been decided. Two points bear emphasizing. First, while Edwards was seen as embodying a somewhat novel approach to constitutional interpretation (known interestingly as the "constituent statute" and not the "living tree" approach), that approach was not that the meaning of the text could change over time to reflect new social norms; it merely acknowledged that the words must be capable of some elasticity to accommodate new circumstances (such as the enactment of the Statute of Westminster). Second, this limited principle was greatly overshadowed by the Privy Council's literalist approach, in which the $B N A$ Act was treated no differently than an ordinary statute. So it was, then, that Browne proceeded to undertake his own exposition of the BNA Act in much the same fashion O'Connor had done almost three decades earlier: through a rigorous and technical evaluation of the words themselves.

The constitutional scholar William Lederman, who perhaps more than any other can be credited with spearheading the movement toward legal instrumentalism in Canada, saw the O'Connor Report and the Judicial Committee as exemplifying the hopelessness of the "literal or grammatical" approach to constitutional interpretation. Both O'Connor and Browne had purported to employ a textualist method, but they had reached opposite conclusions due to the ambiguity of the BNA Act. The solution was to interpret the Act based on the "ongoing life of the country" - focusing less on the words themselves and more on the social and cultural context of modern Canadian society. ${ }^{54}$

Lederman's criticism arguably held the "literalist" or textualist method to an impossible standard. The virtue of textualism was always that it 
reduced, not eliminated, uncertainty and subjectivity by significantly narrowing the scope of plausible interpretation. Browne largely agreed with O'Connor and their relatively narrow disagreement can be examined and assessed with a great deal of objectivity. ${ }^{55}$ But ultimately, it was the view of Lederman and others that would prevail. The judicial function, which Chief Justice Lyman Duff had once summed up as "interpretation and interpretation alone," ${ }^{56}$ soon expanded into the realm of social policy. The development of the "living tree" doctrine coincided with this larger phenomenon and was arguably a function of it; at its core, it was the rejection of formalism and traditional textual analysis in favour of a "sociological" approach to law.

Contemporaries of the Edwards decision such as O'Connor saw it as an affirmation of an existing principle and one that did not significantly affect the basic rule that the BNA Act be construed in accordance with the ordinary principles of statutory interpretation. Within a few decades, the decision had fallen into obscurity and it can be no wonder that Browne viewed Edwards as little more than a footnote in Canadian constitutional history. Browne was writing in the year of the Canadian centennial, and at that time he could state correctly that, after an entire century, the Canadian approach to constitutional adjudication was still one of ordinary statutory interpretation.

The "living tree" metaphor could trace its roots to the Edwards decision, but the living tree doctrine would not take hold until five decades after Edwards had been handed down. Whether or not the modern doctrine is correct in a normative sense has been debated for many years and will most likely be debated for many more to come. But, the historical argument in favour of the "living tree" doctrine, which has long buttressed the normative case, should finally be laid to rest.

The original "living tree" was not an invitation to judges to tailor the Constitution to "the changing political and cultural realities of Canadian society," ${ }^{57}$ but was a recognition of the far more modest proposition that an enduring Constitution had to be capable of some degree of flexibil- ity to accommodate new phenomena such as the invention of airplanes or the enactment of new constitutional statutes. The text alone enjoyed primacy, and while it was not to be interpreted narrowly, the courts were duty bound to apply its fixed meaning. It is this principle, and not the modern living tree doctrine, that was "one of the most fundamental principles of constitutional interpretation" for most of Canadian history.

\section{Endnotes}

* Asher Honickman is a partner at Matthews Abogado LLP, and founder of Advocates for the Rule of Law, a legal think tank. He would like to thank Professor Leonid Sirota for his helpful edits with an earlier draft

12004 SCC 79 at para 22, [2004] 3 SCR 698.

2 Re Section 24 of the BNA Act, [1930] 1 DLR 98, (sub nom Edwards v Canada (Attorney General)) [1930] AC 124 (PC) [Edwards cited to DLR].

$3 \mathrm{Ibid}$, at 106-107. See, for example, Stéphane Beaulac, "Constitutional Interpretation: On Issues of Ontology and Interlegality" in Peter Oliver, Patrick Macklem, Nathalie Des Rosiers, eds, The Oxford Handbook of the Canadian Constitution, (New York: Oxford University Press, 2017) at 893-894,905-908, in which the author argues that "[f]rom Edwards on courts have treated the Constitution as a living tree," capable of evolving to meet changing social circumstances and moral and political views (at 908). The author argues that the "living tree conception introduced in Edwards continued, over the decades to exert its influence in Canada, up to and including the time when efforts were being made to introduce a new constitution" (at 894). See also, Justice Rothstein's lecture in October 2015 in which he discusses the "prevailing view" that Edwards was decided based on the living tree doctrine: Marshall Rothstein, "Checks and Balances in Constitutional Interpretation - Perspectives from a Recently Retired Supreme Court Justice" (McKercher LLP Lecture Series delivered at the College of Law, University of Saskatchewan, 13 October 2015) online: YouTube <https://www.youtube.com/ watch? $\mathrm{v}=\mathrm{H} 1 \mathrm{gAyklurGs}>$.

4 Bradley W Miller, “Origin Myth: The Person's Case, the Living Tree, and the New Originalism" 
in Grant Huscroft and Bradley W Miller, eds, The Challenge of Originalism: Theories of Constitutional Interpretation (Cambridge: Cambridge University Press, 2011). See also Asher Honickman, "The Living Fiction: Reclaiming Originalism for Canada” (2014) 43:3 Adv Q 329; Scott Reid, “The Persons Case Eight Decades Later: Reappraising Canada's Most Misunderstood Court Ruling" (2013) [unpublished], online SSRN: <https:// papers.ssrn.com/sol3/papers.cfm?abstract_ $\mathrm{id}=2209846$

5 Edwards, supra note 2 ("The object of the Act was to grant a Constitution to Canada. 'Like all written constitutions it has been subject to development through usage and convention' [citation omitted]. Their Lordships do not conceive it to be the duty of this Board -- it is certainly not their desire -- to cut down the provisions of the Act by a narrow and technical construction but rather to give it a large and liberal interpretation so that the Dominion to a great extent, but within certain fixed limits, may be mistress in her own house, as the provinces to a great extent, but within certain fixed limits, are mistresses in theirs" at 107 [emphasis added]). See also Reid, supra note 4 at 11-12.

6 Edwards, supra note 2 at 107.

7 British North America Act, 1867 (UK), 30 \& 31 Vict, c 3 [BNA Act].

8 Constitution Act, 1867 (UK), 30 \& 31 Vict, c 3, reprinted in RSC 1985, Appendix II, No 5.

9 Lambe $v$ North British \& Mercantile Fire \& Life Insurance Co, [1886-90] All ER Rep 770, 1887 CarswellQue 2 at para 1 [cited to CarswellQue].

10 Sharpe $v$ Wakefield and others, Justices of the Westmoreland (1888), 22 QBD 239 (CA) ("the words of a statute must be construed as they would have been the day after the statute passed" at 242). See also ibid, at paras 7 and 10 . This rule continues to apply to the interpretation of ordinary statutes. See, for example, $R v$ Perka, [1984] 2 SCR 232 at 264, 13 DLR (4th) 1; Felipa v Canada (Citizenship and Immigration), 2011 FCA 272 at para 71, [2012] 1 FCR 3.

11 Edwards, supra note 2 at 107.

12 Reference as to the Jurisdiction of Parliament to Regulate and Control Radio Communication, [1931] SCR 541 at 546, [1931] 4 DLR 865.

13 Supra note 7.

14 WHP Clement, The Law of the Canadian Constitution, 3rd ed (Toronto: Carswell, 1916).

15 Edwards, supra note -2 at 107.

16 AHF Lefroy, The Law of Legislative Power in Canada (Toronto: Toronto Law Book and Publishing Company, 1897) at 21.

17 Honickman, supra note 4 at 337-338.

18 Reid, supra note 4 at 21.

19 Canada, The Parliamentary Counsel, Report Pursuant to Resolution of the Senate to the Honourable Speaker Relating to the Enactment of the British North America Act, 1867, by William F O'Connor(Ottawa: 17 March 1939) [O'Connor Report].

20 GP Browne, The Judicial Committee and the British North America Act: An Analysis of the Interpretative Scheme for the Distribution of Legislative Powers (Toronto: University of Toronto Press, 1967) [Judicial Committee].

21 These decisions are Attorney-General of British Columbia $v$ Attorney-General of Canada and others [1937] UKPC 9, [1937] 1 DLR 691; Attorney-General of Canada v Attorney-General of Ontario and others [1937] UKPC 6, [1937] 1 DLR 673 [Labour Conventions Reference cited to DLR]; Attorney-General of Canada $v$ Attorney-General of Ontario and others [1937] UKPC 7, [1937] 1 DLR 684. O'Connor Report, supra note 19 at 25.

23 Ibid at 17-18.

24 Attorney-General of Canada v Attorney-General of Ontario and others, [1931] UKPC 93, [1932] 1 DLR 58 at 64 [Aeronautics Reference cited to DLR].

25

37 British North America: A Compilation Based on Sir Joseph Pope's Confederation Documents (Montreal: McGill-Queen's University Press, 2009).

38 Judicial Committee, supra note 20.

39 RCB Risk, "The Scholars and the Constitution: POGG and the Privy Council" in G Blaine Baker \& Jim Phillips, eds, A History of Canadian Legal Thought: Collected Essays, (Toronto: University of Toronto Press, 2006) at 253 ["Scholars and the Constitution"], citing WR Lederman, "Thoughts 
on Refo rm of the Supreme Court of Canada" (1970) 8:1 Alta L Rev 1 at 2-3.

40 "Scholars and the Constitution", supra note 39 at 249-255, 406-419.

41 RCB Risk, "The Classical Age" in G Blaine Baker \& Jim Phillips, eds, A History of Canadian Legal Thought: Collected Essays, (Toronto: University of Toronto Press, 2006) at 253.

42 Judicial Committee, supra note 20 at 6-7.

43 Supra note 33.

44 Judicial Committee, supra note 20 at 20.

45 Labour Conventions Reference, supra note 21 at 684.

46 Edwards, supra note 2 at 107.

47 Judicial Committee, supra note 20 at 24.

48 [1947] UKPC 1, [1947] 1 DLR 801 [AttorneyGeneral of Ontario].

49 British Coal, supra note 31 at 410; Attorney-General of Ontario, supra note 48 at 814-815.

50 (UK), 22 \& 23 Geo V, c 4.

51 Judicial Committee, supra note 20 at 28-29.

52 Ibid at 29 [emphasis added], citing W Ivor Jennings, "Constitutional Interpretation: The Experience of Canada" (1937) 51:1 Harv L Rev 1 at 35.

53 Ibid at 29.

54 WR Lederman, "Thoughts on Reform of the Supreme Court of Canada" (1970) 8:1 Alta L Rev 1 at 2. See also Risk, supra note 39 at 418.

55 See e.g. Asher Honickman, "Watertight Compartments: Getting Back to the Constitutional Division of Powers" (2017) 55:1 Alta L Rev 225 at 230, 234.

56 The King v Dubois, [1935] SCR 378 at 381, [1935] 3 DLR 209.

57 Canadian Western Bank v Alberta, 2007 SCC 22 at para 23, [2007] 2 SCR 3. 
